\title{
RE-ADJUSTMENT IN THE HOME COUNTRY - THE EFFECTS OF RETURN MIGRATION AND TRANSNATIONALISM
}

\author{
Bresena Kopliku \\ University of Shkodra, Albania \\ E-mail: bkopliku@unishk.edu.al
}

\begin{abstract}
This paper analyses how returned and transnational migrants can affect development and social change in the home country. It focuses on the Shkodra Region in Albania. Returnees and transnational migrants use the financial and social capital acquired during migration as mechanisms to readjust in their home country, while at the same time affecting development and social change. The paper deals with a specific returnees' group, entrepreneurreturnees, and raises some main research questions: How is the social and cultural capital gained during migration used while setting up new enterprises? In what scale does this capital determine the success of the undertaking? Acting as agents of development, these migrants have taken advantage of their migration experience, especially in the opening of new enterprises. This process has also involved the non-migrant population through the introduction of new employment possibilities and the transmission of new ideas and knowledge.
\end{abstract}

Key-words: development, entrepreneur returnee, financial capital, social capital, transnationalism

\section{Introduction}

Return migration is a phenomenon that has emerged in the Albanian context, especially after the 2000s. Owing to various reasons, such as the relative improvement of the economic and social situation in Albania, the economic crisis that hit the primary countries of destination-Italy and Greece-, or the desire to invest in the home country, the number of returning migrants has been on the rise, peaking in 2013. The impact of the migration experience is seen especially in how return migrants become self-employed and generate their income. Some return migrants have invested the financial and social capital accumulated over their migration experience in undertakings that have contributed to economic and social changes in their home country. Several theoretical approaches consider migration as a promoter for development in the origin country. In addition to economic remittances and 
diaspora, theoretical approaches also consider return migration as a key mechanism of the migration-development nexus, since it contributes through the repatriation of financial capital saved and enhanced human capital (King, Lulle 2016). Whereas Cassarino explains the involvement of returnee entrepreneurs in regional economic development through the theories of return migration, transnationalism and social network (Cassarino 2014), Boccagni (2013) highlights the notion of social remittances as an indicator of the correlation between migrants and the home-country community.

Previous studies on return migration and entrepreneurship in Albania argue that migrants returning to Albania may be considered as agents of development (Nicholson 2004; Piracha and Vadean 2009). However, this analysis is based mostly on the financial aspect of their contribution and impact. Nicholson argues that the migration literature on Albania takes into account mostly remittances from the monetary perspective, but the positive impact of entrepreneur returnees goes beyond the financial spectrum (Nicholson 2004). While accounting for only a small share of the total number of returnees in Albania, this group has the highest potential for social and economic change, because they bring back capital, training and work experience. In their efforts to re-adjust in the home country, migrants invest their capital and transfer their knowledge, skills and experiences to the local communities in the home country. Therefore, they represent a case of exemplary social change. By setting up new enterprises, return or transnational migrants also affect the non-migrant population by providing new employment possibilities (in a region with high unemployment rates). At the same time, these non-migrant employees have contact with and acquire new knowledge and ideas from their employer, a former migrant.

This paper focuses on a specific group of returning migrants-returnee entrepreneurs-and raises some main research questions: a) How is the employment behaviour of returning migrants adjusted to the new environment in the home country, according to their previous experience in the host country? b) In what ways is the financial and social capital used in the country of origin? and c) How has the development of new enterprises established by different migrants affected the non-migrant community?

The methodology is based on a qualitative approach. Primary data is taken from 14 in-depth interviews with returning and transnational migrants. In order to fully understand the success of returnee entrepreneurs not only according to their personal perspective, I have collected secondary data from the Chamber of Commerce on the number of employees, lifetime of the business and annual revenues. 
Returnees and transnational migrants who invest in Albania rely on their experience and networks they have established in the country of destination to re-adjust to the country of origin. Their jobs during the time of their migration contribute significantly to the kind of entrepreneurship they have established and its success. The most successful entrepreneurs are the returning migrants that have engaged in the same type of business they worked when in emigration. Acting as agents of development, they have taken advantage of this experience specifically by opening new enterprises. Their success is based on the acquired financial and social capital in the countries of destination. The effect of returning migrants' entrepreneurship is multifold. It comprises the financial aspect-financial capital accumulated abroad and invested in the origin country-; and the social capitalknowledge, experiences and networks that are transmitted to the nonmigrant population. In addition, these enterprises involve the non-migrant population by creating new employment possibilities and passing through new ideas and knowledge. Introducing new and previously unknown products and services, they also orient the local producers to increase or diversify their products, in order to meet the enterprises' demand for raw materials. This paper focuses on successful life stories, even though they account for only a small share of the total number of returnees in Albania. The paper has selected successful life stories because their impact is more notable in the local community in the home country. The success of entrepreneur migrants is easily noted and spreads quickly across a small country such as Albania. This is evidenced also by the fact that often they are featured in the media. For most of the returnees, the re-adjustment process is hard, so return migration in Albania is not stable. None of the returnees considers themselves as definitively resettled and prefers to maintain relations with the previous migration country. In order to maximise their possibilities for developing their business initiatives, some of the returnees remain transnational. Transnationalism is also used as a safety plan if the returning migrant tries to migrate again.

\section{Theoretical approach and context}

Whether or not migration leads to development in migrant-sending countries is a debate with both optimistic and pessimistic approaches within the domain of migration studies (De Haas 2010; King and Lulle 2016). Migration can boost development through financial and social remittances, or it can harm development due to brain drain or because it heightens the reliance on migrant remittances and regional inequality (De Haas 2012; Levitt and 
Lamba-Nieves 2011). According to De Haas, the role of migration on development should not be overvalued, and neither should the everyday contributions of returnees or transnational migrants to improve their wellbeing, living standards and economic conditions in the origin country be undervalued. Migration optimists tend to consider migrants as agents of development that act through counter-flows of knowledge and/or through return from the macro level (country) to the meso level (community), as well as on the micro level (De Haas 2012). The impact of migration varies according to the return preparedness, the home country's political, economic and social context or the way remittances are used (Cassarino 2014; Levit and Lamba-Nieves 2011). One of the main channels through which migration may contribute to development is the entrepreneurial behaviour of returning migrants (Triandafyllidou 2016; Naude, Siegel and Marchand 2015; Lucas 2010). Return migration can affect the labour market with this entrepreneurial behaviour from an economic and social perspective. The effects of financial remittances are more visible, but the role of social remittances is also equally important. In addition to money, migrants export ideas and behaviours back to their sending communities, a phenomenon that is known as social remittances. Norms, practices, identities and social capital are the types of social remittances that are exchanged through returning migrants, visits of non-migrants in the destination country, mail, internet, telephone calls, etc. (Levitt 1998). Migrants may bring change by mobilizing the economic, social and cultural resources they have acquired while in their receiving countries. These resources consist of new ideas, and identifying and using them are fundamental elements that determine the success of an undertaking (Brockhaus and Horwitz, 2002):

'When the focus is on micro-level indicators, such as the role of migration in sustaining, securing and improving the livelihoods of individuals, families and communities, one is much more likely to draw positive conclusions than when the focus is on a concept of 'national development'. (De Haas 2012, 14)

Entrepreneur migrants may be returnees or transnational migrants. In the eyes of current scholars, returnees are no longer considered to be returning "forever" to the home country; therefore, return migration is not the last phase or the completion of the migration project. Many of the returnees continue to circulate from one country to the other as transnational migrants (White 2016). In the case of returnee entrepreneurs, transnationalism may be considered a way to take advantage of the opportunities in both countries- 
the country of origin and the country of destination-in order to maximise their income. According to Boccagni and Decimo (2013), social remittances should be analysed based on the literature on migrant transnationalism, especially on transnational families. Research on the latter has highlighted that both migrants and non-migrants, as members of the same households, maintain significant ties. Returnees continue to maintain the transnational networks, which are highly relevant after their return in the economic, social and emotional dimensions. They continue to take advantage of the ties with their former country of residence when they are back in Albania to make their living through the post-return transnationalism (Dahinden 2010, Carling et. al. 2014). Transnational movements may be seen as a strategy for an easier re-integration in the home country, as a way to take advantage of the resources in the country of origin and the country of destination at the same time, or as a "ground" to be used if reconsidering migration.

\section{The Albanian Context}

The local context in the country of origin is also very important. The favourable conditions for enterprises and new investment ideas, the openness of the local communities to new types of services and the awareness of the citizens vis-a-vis their obligations or economic and political stability are additional factors that may either support or prevent the success of the undertaking and the degree of its contribution to social change. Establishing these categories of respondents' enterprises would have been impossible prior to the 2000s in Albania, given the unsettled political situation. Previous studies on remittances in Albania have stressed the propensity of nonmigrants to invest primarily in household consumption, especially in the first transitional decade, taking into account that Albanians were merely surviving in the early years of the transition period (King and Vullnetari 2003).

This paper aims to analyse the role of returning migrants in the regional economic development. It targets a specific group of returnees, the returnee entrepreneurs. According to the Institute of the Statistics Albania (INSTAT) data, the economic growth rate in Albania has been rising recently, and small and medium-sized enterprises (SMEs) have been a significant contributor to such growth. These SMEs represent an engine of growth for the economy and a particular ideology of development (Black, King and Tiemoko 2003, 3). SMEs are considered to be the main pillar of economic growth today in Albania, and some of these enterprises have been set up with funds from migrants or returnees remittances. The stories of success of enterprises set up by returning migrants have been the constant focus of the Albanian media. 
Return migration is known as a strategy in the Balkans, and especially in Albania. The Albanians view migration as an opportunity to accumulate the capital necessary to sustain their families for a certain period of time (Nicholson 2004). While some studies were conducted on return migration in Albania before this year (Nicholson 2001, 2004; King 2003; De Coulon and Piracha 2002; Vullnetari 2007), academia's attention toward return migration grew significantly after 2008 (Goler 2013; Labrianidis and Hatziptokopiou 2010; Mai and Paladini 2013). These studies have focused on the underlying motivations of migrants to return and the strategies they use for readjusting in the home country. Since 2003, King would argue that the lack of facilities and the remote physical infrastructure in Albania presented barriers to return migrants' establishing businesses. Several studies highlight the positive experiences of returning migrants and their skills in managing their lives in both home and destination countries. In 2002, De Coulon and Piracha found that migrants returning to Albania actually earned more than those who stayed behind. Later on, Piracha and Vadean studied the occupational choice of returning migrants by differentiating between the selfemployed and the entrepreneur returnees. They conclude that returning migrants are more likely to be self-employed in business compared to nonmigrants in Albania (Vadean and Piracha 2009).

While there are many studies concerning the entrepreneurship behaviour of returning migrants in Albania, the role of the social capital and cultural capital in this behaviour remains relatively unresearched. The way returning or transnationalism has provided benefits beyond the individual or household level by, for example, employing the community or transmitting skills and knowledge also remains unexplored. This paper also tries to address these two issues as research questions: How is the social and cultural capital gained during migration used while setting up new enterprises? In what scale does this capital determine the success of the undertaking?

\section{Methodology}

The research is based on a qualitative methodology that employs in-depth interviews. The interviewees were selected through personal contacts or friends and colleagues. The interviews were conducted during March 2016. Of the interviewees, one was female, and the others were all male. Males make up the majority of the returnees at both the regional and national level $(73.7 \%$ are male and $26.3 \%$ are female in Albania). They also dominate in the SMEs sector. Women's entrepreneurship performance is still low and remains a challenge in Albania (SME Policy Index 2016). 
The interview questions covered the entire migration cycle of returnees, which involves the return of the migrants to their country of origin. Interviews were first transcribed and then analysed. The interviewees were asked if they wanted to remain anonymous; none of them did. This is in part due to the specific target group: entrepreneurs who considered the interview as a way to promote their business.

The outline of the success of the returnee businesses was realised not merely through in-depth interviews and the returnees' self-perception. The main dilemma for the selected methodology was how to find other elements that completed the framework for the success of returnee entrepreneurs. In order to draw conclusions on the success of the entrepreneurs, I also made a business analysis for each of the enterprises. The analysis results showed that for each business, the number of employees since the business's establishment had increased. Some of them have expanded their business by creating shops/restaurant chains within the Shkodra Region, one within Albania. All of them are regular taxpayer businesses (Shkodra Municipality Data) and most of them plan to continue this business in the future.

\section{Return Migration and Development - The Case of the Shkodra Region}

This paper focuses on the effects of migration in the Shkodra Region. Its population is approx. 207,924 residents, versus 255,898 residents in 2001 (INSTAT 2017). The population decrease is due to the low birth rates, but also because of migration outflows toward more developed countries. At the beginning of the 1990s, the push and pull factors that defined migration were mostly economic factors, and migration was often seen as a survival solution. Today, these factors are much more complex, and the migrants' typology is much more diverse. The typology of migration has changed in terms of causes, destinations and time. There is a growing number of professionals that try to adapt to the labour demand in more developed countries; there is also a continuous increase in the number of high-achieving students who leave the country for better education standards and decide to stay abroad. At the beginning of the transition period, Albanians migrated mostly to Italy and Greece. By contrast, today the migration flows are oriented mainly toward Germany, France, the US and Canada. Even though out-migration is the main type of international migration in the region, there are also other kinds of movements. Circular movements, seasonal migration, return migration and transnational movements have increased since the visa liberalization in 2010, 
enabling Albanian citizens to travel to and throughout the Schengen area without a visa. The liberalisation created a more diverse contemporary migration pattern in the area.

The Shkodra Region has been deeply affected by migration in recent decades. Recently, especially after 2008, the number of the returning migrants has been slightly increasing in this region. According to INSTAT $(2014,41)$, this figure varies from 2,63 to $4,10 \%$ of the total population of the region, and most of the returnees are from Italy. While they are registered as returnees, the Albanian context continues to produce push factors for emigration, and out migration from Shkodra is still occurring. In terms of the labour market, while some migrants have returned and contributed positively to the labour market, many others are still trying to find the ways to legally migrate to developed countries. International movement is also more organized, such as through visa application to Canada and green cards to the USA; there are set processes for students to migrate for educational purposes and for medical professionals to migrate to Germany, etc. The increasing interest to emigrate indicates a lack of economic opportunities; this also raises doubts regarding return migration, which is still sporadic and not sustainable.

Seen as a safety valve for the Albanian economy, remittances have been considered as one of the most positive outcomes of the Albanian migration. At the beginning of international migration, especially during the period of 1990-2000, Albanian migrants tended to spend their savings mainly on consumption, such as housing, food and clothes; financial help for family members in the case of events such as weddings, funerals, and baptisms; the education of children and siblings; or savings for emergency cases, such as disease (King and Vullnetari 2003; Gedeshi 2003). Through the positive lens, even this kind of consumption may be considered as contributing to the income increase and poverty decrease of the non-migrant community. Investing in a new house, migrants invest in construction, thereby creating opportunities for employment and generating income for the non-migrant community (De Haas 2012). In the following years, after having fulfilled some basic standards of living and due to the improvement of Albania's social, economic and political situation, there was a growing interest among migrants in investing financial savings to set up small and medium-sized enterprises in Albania. Evidence from INSTAT and International Organization for Migration (IOM) (2013) reveals interesting differences when comparing migrants' employment and professional skills before migration and after their return. Self-employment increased from $7.4 \%$ of the surveyed migrants before migration to $21.6 \%$ at the time of the survey (INSTAT 2013, 37). It 
must be clarified, however, that not all the returnees are entrepreneurs or self-employed. Returning migrants constitute a heterogeneous group of actors in terms of migration experiences, length of stay abroad, mobilization of resources, legal status and life plans (Cassarino 2016). This paper targets only returnee entrepreneurs. On the other hand, self-employment is an important strategy for many people in Albania, where unemployment rates are high. The returning migrants' capital and social inflows to the country of origin represent an important resource for the development of different enterprises, mainly small and medium-sized businesses.

\subsection{Migration experience abroad, accumulated financial and social capital}

According to Cassarino, "Entrepreneurship" involves more than the act of economically investing in given segments of industry...It also acquires a social dimension that, in turn, impacts on entrepreneurs' patterns of resource mobilization and strategies for survival" (Cassarino 2014, 111). In my research, I found a strong relationship between the work that the migrants have been doing while in the destination country and the work they do in Shkodra. The majority of the interviewees have stayed for a long time in the host country (over 10 years), whereas others stayed for a shorter period (under 5 years) and then returned. In all cases, the period of migration has been long enough for interviewees to accumulate sufficient savings and ideas on how to set up a proper business, which could expand and change in later years. Therefore, migrants prepare a "suitcase of immaterial goods" with diverse and even contrasting contents (Boccagni and Decimo 2013, 14). When coming back, return migrants carry their experience to the home country by playing a key role in sectors such as light industry, fishery, food, leisure and consumption. In the following, I present two cases of migrant entrepreneurs who set up their enterprises based on the work they did in the destination countries. All interviewees continued the same type of activity back in their home country. The following quotes show how work in the destination country shaped the businesses undertaken by return migrants in the home country. Adriatik worked in a fish processing factory while in Naples and Albamilk worked in a dairy while in Puglia.

Adriatik: I migrated in 1991 to Sicily, Italy...I worked there in a fish processing establishment. In the first days of work I asked this question to the other employees, most of them women: "How much does this factory cost?". They would laugh at me... I started doing several jobs at the same time. Meanwhile, I accumulated the needed capital. The 
networks I built in Italy helped me to open the same kind of factory here, in Albania, in 1995. I have to say that it was an Italian friend of mine who came with me to visit Albania, who advised me to take the fishing ship and enterprise in Shengjin (a port in Albania) that was failing...

Adriatik considers his work at the fish processing factory as the key to his success upon returning to Albania. During the conversation, this experience is mentioned often, while the issue of finances remains somewhat ancillary. His former Italian employer helped him to find and target products for new markets. Cassarino refers to this process as the "Preparedness of the returnees", highlighting their ability to mobilize their resources and contribute to development (Cassarino 2004). "The higher the level of preparedness, the greater the ability of returnees to mobilize resources autonomously and the stronger their contribution to development" (Cassarino 2004, 275). Preparation for return for Mare Adriatik seems to have been a combination of many circumstances: working in the fish processing factory and learning about new processing techniques, learning a new technology which was then transferred to Albania, meeting friends working in the same type of operation in Sicily. Adriatik was also in continuous contact with Albania. He considers that maintaining contacts with Albanian friends favoured the acquisition of the fish processing factory after it had gone bankrupt.

A similar combination is noted in the case of Alban. He worked as a handyman for an Italian family in Puglia, Italy, that produced cheese with artisanal methods. Learning about the artisanal and traditional methods of cheese-making, especially mozzarella, cheese production is an advantageous business for Alban. From an Albanian migrant, once received with scepticism, he became the business's most trusted worker, with whom the family shared craft secrets and the skills of milk processing. In later years, after his return to Albania, Alban kept in contact with the Italian family, and he still visits them occasionally and asks for technical help regarding his dairy.

Alban: I migrated in 1991 to Puglia, Italy, and worked there as a handyman in a family restaurant. They used to make their own cheese, mozzarella cheese, at the restaurant. I wanted to learn this technique, so I asked the owner to let me work in the kitchen. I was Albanian, you know, at the beginning of the 1990s, so he obviously did not agree. After some months of hard work, I gained their trust, so they invited me to help inside the kitchen... Meanwhile, I acquired this knowledge that would result so fruitful in Shkoder after my return in 1994. 
The cases in consideration share certain common features. There is a notable correlation between the type of work that the emigrants did while in migration and their line of business in the country of origin. From employees in the country of destination, migrants have become entrepreneurs in the same sector in the country of origin. Both cases deal with former migrants that return to the origin country and start businesses while keeping relationships with the former destination country. They have become transnational entrepreneurs by still using and relying on the knowledge, technology and networks gained in the destination country. Before migrating, none of them had any knowledge or skill about the business they opened after returning home. Financial and social capital gained abroad raised the chances for returning migrants to become entrepreneurs, mostly for small and medium-sized enterprises. The work experience during the migration period facilitated their positive re-adjustment in the home country.

\subsubsection{New possibilities for employment}

Each of the interviewees has employed a certain number of individuals in their enterprise. Given the high unemployment rate in Shkodra, this fact becomes even more significant. For all of the interviewed businesses, the number of employed individuals has increased since the businesses' inception. Migrant entrepreneurs, in addition to utilising financial and social capital, have also contributed to reducing the relative unemployment figures in the region. In addition to the enterprises mentioned here, there are several other new enterprises set up by migrants. As employers, they try to save in labour costs by using the labour force of the country of origin (Kuptsch, Martin 2010,122). Re-exporting [inward processing] industries are the type of returnee enterprises that contribute most to employment. In trade cooperation of the region of Shkodra with other countries, the footwear and textile inward processing is the most notable activity, mainly in trade exchanges with Italy. Some of these products are also sold in Shkodra and across Albania (Gjoni 2014). Comparing the production costs in the country of destination (Italy) with the country of origin (Albania), Artan relocated his enterprise from Italy to Shkodra, employing more than 130 individuals, mostly women. In recent years, the number of employed women from the region has risen, which is explained by the establishment of such enterprises, mainly in the secondary sector.

Artan: After 10 years in Italy, my Italian friend and I decided to open this re-exporting factory in Shkodra, so that we can take advantage of 
the lower labour costs here. The raw material comes from Italy, my employees sew the inside liner of motorcycle helmets and then the product is re-exported to Italy.

The effect of the entrepreneurs in the labour market is also viewed from the perspective of boosting the demand for raw materials and services which they obtain locally. Entrepreneurs take their raw material from the region, so they have oriented some of the local production according to their needs for supply. This is the case of Xhafer. He considers himself lucky to have been able to work for a prestigious restaurant in England, which provided him with the knowledge to pursue his passion. Xhafer has learned a lot about how to cook and how to combine different spices and plants, whose value he previously didn't understand. The knowledge he has acquired has helped him appreciate local products and use them more frequently in his dishes. Most of the local products, whether cultivated or naturally grown, previously unknown or used very little, are now part of various dishes. The local residents have also started to use some of them. Xhafer also mentions that he has learned how to interact with clients and how to share duties and responsibilities with the employees.

Xhafer: I have worked in England for 14 years as an assistant chef. Cooking has always been my passion and I was eager to learn as much as possible from the experience of working in prestigious restaurants. Some of them had earned Michelin stars. I still explore new ideas of combining elements, which I find locally. We collect around $90 \%$ of the meat and vegetables from the local families here in the region.

Alban shares the same approach to addressing the local community for the raw material. He has set up a dairy factory that produces cheese and other products from milk. It is located in the suburban area of the city, which in the Socialist period was well known for its high quality of dairy and meat products. After the fall of Communism, many informal buildings were built in this area, and the residents abandoned animal farming. The opening of these dairy factories fostered some residents to turn back to their old occupation.

Alban: I have established my enterprise in this area because it is known for the high-quality milk, of which I collect sometimes 5.000 to 6.000 litres a day. Our products are intended for the supermarkets and restaurants of the region. 
Albania has changed greatly since the fall of Communism. White considers the rapid growth of international migration, transnational networks and new international employment possibilities as the most significant factors shaping the lives of many citizens in the post-Communist countries (White 2016, 406). New opportunities during the transition period, which were previously nonexistent, have expanded investment opportunities. In the case of returnee entrepreneurs, the social capital and the acquired knowledge have been very helpful in the re-adjustment process. The cheaper labour force in the origin country compared to the destination country motivates some migrants to return as employers, shifting production from the higher-wage countries to the lower-wage ones. This usually happens in collaboration with a partner from the destination country, creating thus networks of production or joint ventures. The investment of new ideas and the exploration of new experiences contribute to the success of the entrepreneur, and to the diversification of employment opportunities for the non-migrant community. Social remittances, however, have a major influence on the outcomes of economic remittances.

\subsubsection{Social remittance transfer and transnational ties}

Within the migration-development nexus, social remittances are a very important and powerful component (King amd Lulle 2016). "As they send money, migrants simultaneously send immaterial goods that distinctively impact on social and cultural discourses, meanings and practices - in ways that span beyond any strictly economic effect" (Boccagni and Decimo 2013, 5). Following Levitt (1998), we define social remittances as "ideas, behaviours, identities and social capital that flow from receiving to sending countries communities" (Levitt 1998, 927). Return migration, whether temporary or permanent, and transnational movements are the main channels through which social capital is transferred to the origin country. This transfer of human and social capital may be affected through the permanent and temporary return, the investment in human capital in the origin country, and the transnational social activities during migration or after return (Black et. al. 2003). Returnees and transnational migrants transfer their knowledge and skills to the non-migrant community: friends, family, etc. While a significant inflow of money from abroad is a clear and distinctive fact, its impact on local development depends on the relational circuits into which it is embedded, and on the social value with which it is credited (Boccagni and Decimo 2013, 6). Endi and Era used to work in Italy in a pasta restaurant. They are a couple who is used to doing hard work in Italy and tries to keep the same pace in Albania, and they expect the same from their employees. 
Endi: I have taught all the waiters we have. I chose the waiters' chief among the electricians that were working in the building. I preferred to teach him from scratch.

Highly-skilled returnees have also had a major role in starting up new business ventures upon returning home (Lucas 2010). "When returnees do recognize themselves as bringing cultural change, one reason can be that the variety of new ideas and practices are already gaining popularity in the origin society for different reasons and they are simply contributing to these" (White 2016). Elvis has recently returned from Italy. He has studied pharmacy there and has opened a tea room in Shkodra. He explains that his knowledge in mixing different plants gave him the idea to open a bar with different kinds of tea. It is a small family-run business that attracts many young people, tourists and students alike, who find the low-cost bar very interesting. Most of the furnishings and utensils are recycled materials: old wooden chairs, jars, etc.

Elvis: Many of my friends and cousins are engaged in my activity: my cousin works in the bar, his sister washes the dishes, my aunt cooks the biscuits and cakes...They were very helpful, especially at the beginning, when I did not have enough money to employ someone...

The benefits from an emigration experience are not limited only to the highly skilled. During their migration experience, migrants acquire certain "work habits" such as being punctual, working hard, saving money, being more careful with the disposal of litter, paying taxes regularly and asking for better standards of health and education; They thereby construct a transnational identity, which may be turned into a positive contribution if fostered from contextual factors (Davids and Van Houte 2008, 181). These values may be considered as an asset to development, especially if they have an impact on the surrounding social environment. Knowing friends and creating the right networks during migration has served as a pillar for many interviewees to set up their business. This social capital-a set of interpersonal relationships that facilitate individuals and groups in reaching their objectives-is considered as a source of benefits through extra family networks and identified as a key resource for the creation of small businesses (Portes 1998). The success of the enterprise depends on the relevance of the social capital, meaning how it can be used to get essential resources in order to save money, time and energy. As stated by Cassarino, additional resources that have to be taken in consideration when analysing the link between entrepreneurship and return are the family support and the networks of 
acquaintances and friends in the country of origin (Cassarino 2014). Connections with the country of origin are equally important. The success of the enterprise in Albania, where informality remains significant, depends on setting up the "proper ties" and their type. Adi travels frequently between Albania, Italy and Kosovo, where he is working to expand his activity. The social capital he has is embedded in the transnational social field. Crossborder relations help him to succeed, but also affect social change.

Adi: I migrated in 2000 and returned in 2014. I did all kinds of jobs at the beginning, washing the dishes or cleaning a bar in Milan. It was known for its cocktails...I was lucky to meet two famous Milanese barmen, who taught me everything on cocktails. I still keep in touch with them, visit them often and they come to Albania too. I have tried to find the suitable people for managing the bars I have opened in Shkodra and Korca (two Albanian cities), which, honestly, is not an easy endeavour...

Maintaining social capital is considered as very important by all the entrepreneurs. They frequently visit the previous country of emigration for two main purposes: first, for business matters such as purchasing equipment, raw material, collecting new ideas; and second, maintaining the relations as a plan B should they emigrate again.

\section{Conclusion}

Studies on return migration in Albania note remittances were used mainly for consumption during the first decade of transition (1990-2000) and for investments after 2000. Most literature focuses on financial remittances and does not address social remittances. While the role of financial remittances in the everyday lives of migrants' family and relatives living in Albania is often highlighted, the way in which the knowledge and skills are transferred to the non-migrant community remains unexplored. Financial remittances have had a notable impact on the development of Albania, and social remittances have been equally important. However, social remittances are difficult to trace. Even though difficult to identify, social remittances affect the outcomes of financial remittances. Although limited in number, returning migrants that have established their enterprises are key players that have contributed to development. Shifting from the consumption of these remittances to investing them is a qualitative step in Albanian contemporary migration. However, not all the returnees are successful; on the contrary, only a few of them are. 
Nevertheless, this minority of returnees analysed in the paper-positive returnee entrepreneurs - can be actors of social and cultural change.

The degree of their impact is related to the degree of success, which, in turn, is dependent on a number of factors. A surprisingly strong relationship has been found between the migrant employment in the host country and their employment in Shkodra. All interviwees work in the same service as in the host country but now in the role of the employer. Financial and social capital gained abroad raised the chances for them to become entrepreneurs, mostly for small and medium enterprises. Migration experience, though often difficult, has given them the chance to accumulate a certain amount of money, which proved to be valuable in Shkodra and could be invested. At the same time, social capital has had the same role in the success of their enterprises. Some interviewees worked in bars, restaurants, the fishing industry, agriculture, and construction in the host countries, while others completed their studies there, mainly in Italy. They returned with knowledge, enriched experiences, a mindset of hard work, new friends and business partners and other kinds of connections that they still maintain. These are some, though not all, of the elements which have had their positive implication in their own success.

The entrepreneurial behaviour is one of the main channels through which return migration contributes positively to development. The returning migrants have advanced the entrepreneurial spirit during their migration period. All the enterprises are unique and reflect their creative spirit. These ideas are based on the work they used to do in the country of destination, and the innovation is reflected not only in the type of business, but also in the kind of materials they use, or the way they organise the work and communication with their employees. In this way, while working to achieve success for themselves, the entrepreneurs have also contributed to the local community in their country of origin. This contribution can be seen in several ways: the number of employees in these enterprises, the diversification of the labour market according to the entrepreneurs' supply needs, the transfer of knowledge and skills as reflected in the efforts to replicate the model by the local people. In spite of this success, the sustainability of return migration is put into question. The transnational behaviour and the preservation of social capital-not only for business purposes but also as an opportunity-in the case of re-emigration show that in the re-adjustment process, financial welfare is not all that counts. 


\section{References}

Black, Richard, Russell King, and Richmond Tiemoko. 2003. Migration, Return and Small Enterprise Development in Ghana: A Route out of Poverty? University of Sussex: Sussex Centre for Migration Research, Globalisation and Poverty.

Boccagni, Paolo, and Francesca Decimo. 2013. "Mapping Social Remittances.” In Migration, Editorial Letters 10: 1-10.

Brockhaus, Robert H., and Pamela S. Horwitz. 2002. "The Psychology of the Entrepreneur." In Entrepreneurship: Critical Perspectives on Business and Management, Norris F. Krueger, Vol. 2. Taylor and Francis.

Carling, Jorgen, and Marta Bivand Erdal. 2014. "Connections between Return Migration and Transnationalism." International Migration 52 (6): 2-12. https://doi.org/10.1111/imig.121 80.

Cassarino, Jean-Pierre. 2000. Tunisian New Entrepreneurs and Their Past Experiences of Migration in Europe: Resource Mobilization, Networks, and Hidden Disaffection. Aldershot: Ashgate.

Cassarino, Jean-Pierre. 2014. Return Migrants' Entrepreneurship. Return Migration and Development Platform (RDP); CRIS; Analytical Study. Florence: European University Institute, Robert Schuman Centre for Advanced studies.

Cassarino, Jean-Pierre. 2016. "Return Migration and Development: The Significance of Migration Cycles." In Routledge Handbook of Immigration and Refugee Studies, 351-62.

Dahinden, Janine. 2010. “Are You Who You Know? A Network Perspective on Ethnicity, Gender and Transnationalism: Albanian- Speaking Migrants in Switzerland and Returnees in Kosovo." In Identity Processes and Dynamics in Multi-Ethnic Europe, 127-44. IMISCOE Research. Amsterdam University Press.

Davids, Tine, and Marieke Van Houte. 2008. "Remigration, Development and Mixed Embeddedness: Am Agenda for Qualitative Research?" International Journal of Multicultural Societies, The conditions of Modern Return Migrants, 10 (2): 169-94. 
Coulon, Augustin de, and Matloob Piracha. 2002. Self-Selection and the Performance of Return Migrants: The Case of Albania.

European Union. 2016. Annual Report on European SMEs 2015/2016.

Gjoni, Flora. 2014. "Roli I Sektorit Terciar ne ekonomine e Rrethit Te Shkodres." University of Tirana.

Göler, Daniel. 2013. "Remigration, Transition and Development. Aspects of Multilocality and Social Resilience, with Albania as an Example." International Conference in the framework of the IGU-Commission on 'Globility' presented at the Migration, Emigration, Return Migration Perspectives from Sending and Receiving Countries.

Haas, Hein De. 2012. The Migration and Development Pendulum: A Critical View on Research and Policy'. In International Migration 50 (3): 8-25. Blackwell Publishing Ltd.

Instituti i Statistikave INSTAT. 2014. Migracioni në Shqipëri [Migration in Albania],. Tiranë: Gent Grafic.

Instituti i Statistikave INSTAT, Organizata Ndërkombëtare për Migracionin (ONM). 2014. Migracioni I Kthimit Dhe Ri-Integrimi Në Shqipëri. Tiranë: Gent Grafic.

Labrianidis, Lois, and Panos Hatziprokopiou. 2010. Albanian Return Migration: Migrants Tend to Return to Their Country of Origin after All. http://ec.europa.eu/.

Levitt, Peggy, and Deepak Lamba-Nieves. 2011. "Social Remittances Revisited." Journal of Ethnic and Migration Studies 37 (1): 1-22.

Lucas, Robert. 2010. "Migrant Sending Countries, the Internalization of Labour Markets and Development." In The Internatinalization of Labour Markets, edited by Christian Kuptch, 63-71. International Labour Organization (International Institute for Labour Studies).

Mai, Nicola, and Cristiana Paladini. 2013. "Flexible Circularities: Integration, Return, and Socio-Economic Instability within Albanian Migration to Italy." In 
Circular Migration between Europe and Its Neighbourhood: Choice or Necessity? Oxford Scholarship Online.

Naude, Wim, Melissa Siegel, and Katrin Marchland. 2015. "Migration, Entrepreneurship and Development: A Critical Review." Working Paper. Maastricht, The Netherlands: United Nations University UNU-Merit.

Nicholson, Beryl. 2001. "From Migrant to Micro-Entrepreuneur: Do-ItYourself Development in Albania." South-East Europe Review 4 (3): 39-41.

Nicholson, Beryl. 2004. "Migrants as Agents of Development: Albania Return Migrants and Microenterprise." Policy Documentation Centre Romania.

King, Russell, and Aija Lulle. 2016. Research on Migration: Facing Realities and Maximizing Opportunities. European Union.

King, Russell, and Julie Vullnetari. 2003. Migration and Development in Albania, Vol. C5. Migration, Globalisation and Poverty Working Paper. Sussex Centre for Migration Research: Development Research Centre on Migration, Globalisation and Poverty.

Piracha, Matloob, and Florin Vadean. 2009. "Return Migration and Occupational Choice." School of Economics discussion papers 9 (5).

Portes, Alejandro. N.d. "Social Capital: Its Origins and Applications in Modern Sociology." In Annual Review of Sociology 24: 1-24. JSTOR. http://www.jstor.org/stable/223472.

Triandafyllidou, Anna. 2016. "Migration and Asylum in the Twenty-First Century." In Routledge Handbook of Immigration and Refugee Studies, 1-23. London and New York.

Vertovec, Steven. 2002. "Transnational Networks and Skilled Labour Migration." In WPTC-02-02. Ladenburg.

Vullnetari, Julie. 2007. "Albanian Migration and Development: State of the Art Review." IMISCOE Working Paper, IMISCOE 18. http://edoc.bibliothek.unihalle.de/servlets/MCRFileNodeServlet/HALCoRe_derivate_00003672/Alban ianmigration.pdf. 
61 | RSC Volume 11, Issue 1, January 2019

White, Anne. 2016. "Informal Practices, Unemployment, And Migration in Small-Town Poland." East European Politics and Societies and Culture 30 (2): 404-22. 